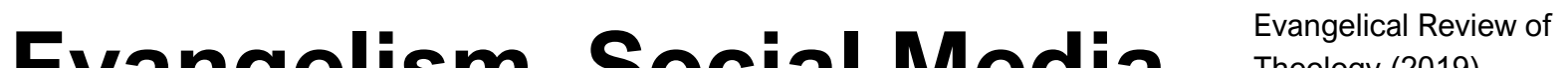 Evangelism, Social Media, trobolys(2019) and the Mum Effect \\ Vol. 43, Issue 2, pp. 138- \\ 151
}

\author{
David R. Dunaetz
}

Azusa Pacific University

\begin{abstract}
The Mum effect is the natural human reluctance to share bad news with others, due to a desire to avoid a range of negative consequences, consequences affecting both self and the recipient of the bad news. Although the gospel is good news to those who believe, it may be viewed negatively by those who do not believe. Thus, Christians may be hesitant to share the gospel because of the negative consequences associated with the Mum effect. Because of the anonymity of the internet, social media is often filled with unrestrained criticism of Christianity. This may amplify the perceived negative consequences of sharing the gospel with unbelievers. In light of this cultural evolution, found now in the global north and increasingly present in the global south, Christian leaders can lead more effective ministries by distinguishing between outreach (building relationships in a way that makes the gospel attractive), witnessing (explaining how one has experienced God), and evangelism (sharing all that is necessary to make a decision for Christ), and by ensuring that all three occur in culturally relevant ways, carried out by individuals best equipped to do each, in a way consistent with the New Testament teaching on spiritual gifts. Specifically, outreach and witnessing can be done by all Christians who interact with non-Christians, whereas evangelism may be carried out, both on the individual level and in large groups, by those who are appropriately gifted. By addressing large groups in a more impersonal way, those gifted in evangelism may reduce the negative consequences of the Mum effect and build upon the outreach and witnessing done by others.
\end{abstract}

Key Words: Mum Effect, Social Psychology, Evangelism, Social Media

As cultures evolve due to advances in technology, missionaries and other Christian leaders need to develop the most effective strategies for sharing the gospel with those who have not put their faith in Christ and discipling those who have. Various psychological phenomena come into play as technology, especially social media, evolves and influences not only cultures of the global north, but those of the global south as well. One such phenomenon is the Mum effect (Dibble, 2017; Rosen \& Tesser, 1970; Tesser \& Rosen, 1975; Uysal \& Öner-Özkan, 2007), the reluctance that people feel to share bad news with others. People tend to remain mum (hence 
the name of the effect) about information that may be perceived negatively by others. For example, doctors find it very difficult to inform patients that they have a terminal disease (Fallowfield, Jenkins, \& Beveridge, 2002). Rather than communicate the truth concerning the patient's condition, it is often easier for the doctor to conceal the information, avoiding the awkwardness that would accompany revealing the patient's true condition. Similarly, Christians may find it difficult to share the gospel with unbelievers, anticipating the awkwardness that might accompany such a discussion.

\section{The Mum Effect}

Originally studied in the 1970s in light of advances in medicine which had made the diagnosis of various terminal illnesses more common (Kelly \& Friesen, 1950; Rosen \& Tesser, 1970; Tesser \& Rosen, 1975), the Mum effect can be defined generally as the reluctance to share bad news. However, this reluctance is not universal. Media sources provide endless accounts of bad news and stories about people's destructive behaviors are readily shared privately in social networks. The reluctance to share bad news is limited to interpersonal conversations with a person who is directly affected by the bad news. A more precise definition of the Mum effect is thus "the reluctance to transmit bad news. . . to the person for whom the news is bad" (Tesser \& Rosen, 1975, p. 195).

In the original experiment which demonstrated the Mum effect (Rosen \& Tesser, 1970), participants were assigned to one of two conditions. Each was placed in a waiting room and then asked to inform another person who appeared to be waiting (and who had stepped out of the room) that he or she should call home because there was some good news (in the first condition) or bad news (in the second condition). The participants in the bad news condition informed the person of the valence of the news (whether it was good or bad) far less often (26\% of the time) than those in the good news condition ( $82 \%$ of the time). This demonstrates a common strategy that people use when needing to present bad news to others: only transmit part of the information to the recipient, the part which is least likely to be upsetting.

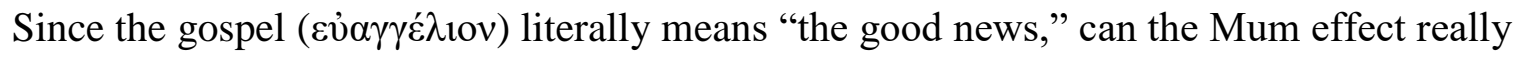
help explain why Christians are hesitant to share the gospel with others? It is important to note that the gospel is perceived differently by those who believe and those who do not believe. "The word of the cross is foolishness to those who are perishing, but to us who are being saved it is the power of God" (1 Cor. 1:18, NASB). The gospel is good news only to those who believe; to those who do not believe it is bad news. "We are a fragrance of Christ to God among those who are being saved and among those who are perishing; to the one an aroma from death to death, to the other an aroma from life to life" (2 Cor. 2:15-16a, NASB). Most Christians who have tried to share the gospel with others, especially with those who reject the gospel, know that it can be very awkward, even painful, to explain mankind's need for salvation and God's provision through Jesus Christ to those who refuse to believe. The "offense of the cross" (Gal. 5:11) is real. Although Christ's offer of salvation is good news for those who believe, our status before God, 
as well as our own inability to do anything about it in ourselves, is bad news for those who do not believe.

There are several reasons that humans are reluctant to transmit bad news. In any given situation, it is likely that one or more of these reasons come into play, perhaps at different times. The psychological underpinnings of the Mum effect can be classified into two main categories, concern for the other party (the recipient of the bad news) and concern for oneself (Bond \& Anderson, 1987; Dibble, 2017; Dibble \& Levine, 2013; Tesser \& Rosen, 1975; Uysal \& ÖnerÖzkan, 2007).

\section{Concern for the Recipient of the Bad News}

One of the reasons that people are hesitant to share bad news with others is that the recipient of the bad news often feels bad upon receiving the news. In Mum effect experiments, when participants were asked why they were unwilling to transmit bad news to someone to whom the bad news was important, concern for the recipients' feelings was the most common reason given (Tesser \& Rosen, 1975). The person who delivers the bad news indirectly causes, by choosing to communicate the bad news, malaise or even pain in the recipient (Dibble, 2017; Tesser \& Rosen, 1975). According to self-determination theory (Deci \& Ryan, 2008; Ryan \& Deci, 2000), almost all humans are motivated to improve (or at least maintain) the quality of relationships with those around them. Humans generally do not want to hurt other individuals who do not pose a threat of some kind or who are not envied for some reason or another. By choosing not to transmit bad news, a person avoids (at least temporarily) causing pain to another and thus maintains the relationship.

In addition, this concern for others' feelings is amplified if the recipient of the bad news is known to have especially strong negative reactions to unpleasant information (Tesser \& Conlee, 1973). People also tend to believe that recipients do not want to hear bad news, although they believe that they themselves would want to hear it (Conlee \& Tesser, 1973). It is quite likely that Christians tell themselves that non-Christians do not want to hear the gospel, although they would willingly admit that they themselves had been glad to hear it. These early studies of Mum effect also found that if people knew the recipients wanted to hear the bad news, they were far more willing to share the news with them (Conlee \& Tesser, 1973). Given this phenomenon, useful strategies Christians can use to share at least parts of the gospel include telling personal stories (which most people enjoy hearing) and simply sharing a Christian perspective on some topic that is already a subject of an enjoyable conversation. These strategies will be discussed in more depth later. 


\section{Concern for One's Own Interests}

Although concern for the recipient's feelings is associated with one set of factors that leads to the Mum effect, it is likely that concern for one's own interests is also a motivator. These interests include one's own feelings and on how one is evaluated by others.

Desire to Avoid Negative Feelings. Experiments have demonstrated that after sharing negative information with other people, one's own mood goes down (Tesser \& Rosen, 1975; Tesser, Rosen, \& Batchelor, 1972). This occurs because of the phenomenon of emotional contagion, "the tendency to automatically mimic and synchronize expressions, vocalizations, postures, and movements with those of another person's and consequently, to converge emotionally" (Hatfield, Cacioppo, \& Rapson, 1993, p. 96). People can unintentionally adopt the moods and emotions of others, especially negative moods and emotions, in almost any context where emotion is being displayed and interaction occurs, both in face-to-face communication and in electronically mediated communication (Kramer, Guillory, \& Hancock, 2014).

People are generally motivated to seek positive feelings. However, when they share bad news with someone, they may adopt the negative feelings that they imagine or see in the recipient. From a social exchange (or cost-benefit) perspective, sharing bad news is costly; if a person is feeling good, he or she may lose this valued state upon sharing the bad news, experiencing negative feelings which are far less valuable (Cropanzano \& Mitchell, 2005; Tesser \& Rosen, 1975). This desire to avoid negative feelings and moods may sometimes be a motivating factor behind the Mum effect.

Self-Presentation Concerns. Although the desire to avoid negative feelings or the desire to protect the recipient from pain may be present when the Mum effect occurs (Dibble, 2017), it appears that the strongest driving force behind the Mum effect is the desire to protect one's reputation (Bond \& Anderson, 1987; Dibble \& Levine, 2013; Tesser \& Rosen, 1975; Uysal \& ÖnerÖzkan, 2007). By simple association, the person who brings negative news will be linked to this news and the negative feelings it creates. The Earl of Northumberland, in Shakespeare's Henry $I V$, Part 2 (Act 1, Scene 1) says, "The first bringer of unwelcome news hath but a losing office and his tongue sounds ever after as a sullen bell remembered tolling a departing friend." When a person is associated with negative feelings, the person (even when they are not the cause of the negative feelings) is more likely to be evaluated negatively or judged by the person experiencing the feelings.

This negative association has been demonstrated in a behavior-focused experiment (Manis, Cornell, \& Moore, 1974). People who delivered messages which created negative feelings were judged more severely than people who delivered messages that the recipient wanted to hear. This phenomenon of wanting to "shoot the messenger" is not a new phenomenon. Jesus exclaimed that the city of Jerusalem systematically put to death the messengers of God who brought unpleasant news (Luke 13:34), such as the prophets Uriah (Jer. 26:20-23, Heb. 11:37) and Zechariah (Matt. 23:35). The Northern Kingdom also had a history of killing prophets (e.g., I Kings 18:14). Jesus himself was put to death because of the negative sentiments that announcing 
his identity produced in the religious leaders (Mark 14:60-64). After Christ's death and resurrection, the trend continued; for example, the Apostle Paul was imprisoned several times for announcing what was interpreted as very bad news (e.g., Acts 22:22-24).

Why does the desire to protect one's reputation (or save face) lead to the Mum effect? People are innately motivated to want to be positively evaluated by others. Our self-esteem is strongly affected by how others evaluate us (Leary, 1996; Leary, Tambor, Terdal, \& Downs, 1995). Negative evaluations lead to a sense of social exclusion which creates feelings of loneliness, anxiety, and despair (Leary, 1990). Thus people avoid behaviors that lead to negative judgments and are motivated to perform behaviors which lead to positive evaluations by others, a strategy known as self-enhancement (Swann, 1990). Thus one of the goals in most, but not all, human interactions is to be evaluated positively by the other.

When interacting with others, we tend to have this goal of wanting to be evaluated positively by them. One very common way of doing this is ingratiation (Jones, 1964), "selfpresentation tactics that aim to present a likeable image" (Uysal \& Öner-Özkan, 2007, p. 67). Three common forms of ingratiation (Jones \& Wortman, 1973) are other enhancement (saying positive things about a person or about something associated with the person in such a way that the person knows that the speaker has said them), opinion conformity (agreeing with a person's beliefs or values), and favor doing (doing something to benefit a person in a way that will motivate the person to act beneficially to the speaker due to reciprocity norms of behavior). When interacting with a person, sharing good news with that person can be used to perform all three forms of ingratiation; these pleasant conversations are characterized by other enhancement, opinion conformity, and favor doing. They are typically appreciated by the receiver of the good news and thus enhance the reputation of the one presenting the good news. However, sharing bad news can have exactly the opposite effect.

Consider the example of two Christians, Adam and Ben, who both wish to invite a nonChristian friend Chris to church. If Adam has communicated to Chris that there are some things about him that he really appreciates (other enhancement), that they share a lot of values concerning social issues and personal responsibility (opinion conformity), and information about a reliable local air conditioning repairman (favor doing), there is a strong possibility that Chris has concluded that Adam is trustworthy and will accept his invitation to come to church with him. With each act of ingratiation which contains some element of positive news, Adam has earned the trust of Chris and has increased his ability to influence him.

In contrast, consider Ben's interactions with Chris. Ben has communicated to Chris that he needs to become a Christian because of his sin, that Ben does not agree with Chris' tolerance of homosexuality, and that the painter Chris hired to paint his house did a poor job. It is likely that from Chris' point of view, Ben is someone to avoid. Ben is a continual source of bad news and negative judgment. If Ben tries to share more of the Gospel with him, Chris will probably sense more bad news coming. He will likely find an excuse to end the conversation with Ben and will try to avoid future interactions with him. 
In reality, unless Ben has very poor social skills, it is unlikely that he would have shared all this negative news with Chris. Ben most likely would prefer to come across as a good neighbor. The desire to not offend or sadden Chris, or to not be ostracized by Chris would push Ben toward more socially acceptable behavior, such as remaining mum about such information. The social pressures behind the Mum effect normally prevent such negative interactions from occurring.

\section{Social Media Effects on Sharing the Gospel}

Although the social forces behind the Mum effect have always existed and thus may have discouraged Christians from sharing throughout church history, the nature of internet-based social media has amplified these effects and has made evangelism even more difficult in the present context.

Social media, including Facebook, Twitter, Instagram, and a multitude of newer networks that may or may not become household names, have an enormous impact on modern culture, especially on Millennials and Generation Y (Lenhart, Purcell, Smith, \& Zickuhr, 2010; Twenge, 2014). The smartphone has created a world where most people are never a few inches, taps, and swipes away from finding out what other people are thinking and saying about them (Poushter, 2016).

On the positive side of this societal transformation, social media makes both asynchronous and synchronous exchanges of information with a large number of people very easy. It permits the development of relationships through the exchange of information in a controlled environment, which can be especially attractive to people who are less at ease in face-to-face situations (Dunaetz, Lisk, \& Shin, 2015). On the negative side, it encourages continual social comparison (Fazio, 1979; Festinger, 1954) between users, many of whom use social media to portray an idealistic lifestyle to create a positive image of themselves to others. This appears to be creating a culture of feeling inferior or insufficient compared to others (Vogel, Rose, Roberts, \& Eckles, 2014). Cyberbullying has also become a common phenomenon, creating fear that one will be publicly ridiculed or humiliated for any beliefs or behaviors outside of the social norms promoted by the bully, often leading to stress and suicidal ideation (Kowalski, Giumetti, Schroeder, \& Lattanner, 2014). Since around 2012, when Americans and Europeans with smart phones first outnumbered those without smart phones, teen depression and suicide rates have increased dramatically, especially among teenage girls (Twenge, 2017; Twenge, Joiner, Rogers, \& Martin, 2018). The technology-inspired cultural transformation which is occurring has a dark side which can create many undesired effects.

This continual influx of information, which is often accompanied by comments written in an aggressive tone by people with a social or political agenda, can have a negative effect on Christians and their willingness to share the gospel with others. Because people can anonymously criticize and attack others with impunity, Western culture's narrative around Christianity has morphed it into an oppressive and intolerant worldview that is inacceptable in modern socie- 
ties (Eberstadt, 2016). Christians are typically described as intolerant extremists who are cruel or insensitive to the felt needs of others and are dismissive of science, and people who were raised as Christians often portray themselves as former believers who have rationally decided to reject Christian beliefs and values because of their lived experiences (MediaSmarts, n.d.). Such stereotypes may instill fear in Christians and discourage them from revealing their Christian identity online in order to avoid being labeled or criticized inappropriately. This "escalation of fear" (Altheide, 2013, p. 223) enables the dominant contributors to the new media to exert a disproportionate influence over those who primarily consume it.

Essentially, Christianity is presented in a Christian's social media as bad news. The exception would be social media, such as Facebook, that filters by political or religious content and creates an echo chamber effect where the user is primarily exposed to people who share his or her worldview or to advertisements designed to evoke anger and reinforce one's beliefs (Bakshy, Messing, \& Adamic, 2015; Colleoni, Rozza, \& Arvidsson, 2014; McPherson, SmithLovin, \& Cook, 2001). But because people, especially Millennials and Generation Z (or the iGeneration), spend so much time on social media, their worldview is strongly influenced by the loudest voices on social media (Twenge, 2014; Twenge et al., 2018). The ubiquitous criticism of Christianity amplifies the fear of rejection associated with sharing the gospel, both online and in person. The Mum effect is perhaps stronger now than at any time in the last millennium for most Christians, especially in the global north. Although most non-Christians who personally know evangelical Christians view Christians positively (Barna Group, 2015; Pew Research Center, 2014), the risk of rejection, criticism, and losing face due to the Mum effect can easily be overestimated by Christians. The highly visible criticism of Christians in social media increases the fear of being a bearer of bad news in all areas of life.

In an increasingly secular context, the growing reluctance to share the gospel makes fulfilling the Great Commission even more difficult. What can Christian leaders do to combat this phenomenon? How can the gospel be presented as good news rather than bad news?

\section{Distinguishing Between Outreach, Witnessing, and Evangelism}

One approach that Christian leaders can take to reduce the increased reluctance to share the gospel due to the Mum effect is to clearly distinguish between various aspects of sharing the Christian faith with others. If we roughly define outreach as building relationships, witnessing as sharing stories of what one has experienced with God, and evangelism as presenting all that a person needs to know to make a decision to follow Christ, then each of these aspects of sharing one's faith can examined in light of the mum effect and the New Testament concept of spiritual gifts. Some aspects of sharing one's faith can be done on the interpersonal level with less perceived risk of rejection and criticism, reducing the consequences of the Mum effect. In addition, it may also increase the likelihood that non-Christians receive a more complete and comprehensive exposure to the gospel so that they can make informed decisions to follow Christ or not. 


\section{Outreach to Build Relationships}

Outreach, as defined in the field of sociology, occurs "when help, advice, or other services are provided for people who would not otherwise get these services easily" (Longman, 2015). Although often thought of as a particularly Christian concept, the term is used in both forprofit and nonprofit secular organizational contexts. In Christian contexts, outreach activities take on many different shapes, such as afterschool-tutoring services for neighborhood children, a coffee shop run by young adults, meals provided to the homeless living near the church, a Halloween-alternative festival, or services provided to women caught up in human trafficking. The purpose of these outreach activities varies according to the context. Sometimes the only purpose of the activities is to provide services or information to the recipients of the services. In other cases, when outreach is conceptually linked to evangelism, the purpose is to develop relationships with people outside of the church, with the goal that these relationships might influence them to become Christians.

However, a clear distinction needs to be made between outreach and evangelism. In contrast to outreach, which we have defined as simply seeking to build a social link between a nonChristian and a Christian, or between the non-Christian and the church, we define evangelism as communicating all the information necessary to make a decision to follow Christ, typically in a structured, detailed presentation. Outreach by itself does not imply that anyone will hear the entirety of the gospel message in such a way that he or she can make an informed decision about following Christ. Although outreach is necessary, it is not sufficient for most people to make a decision to follow Christ. Dunaetz and Priddy (2014) found that the value that the head pastor placed on outreach was, in fact, a negative predictor of numeric church growth. This is perhaps due to emphasizing outreach at the expense of evangelism. Outreach without evangelism may be a sign of a church's decline, perhaps due to an inability or a lack of desire to share the gospel with the people contacted through outreach. Outreach must be accompanied by evangelism to lead to numeric church growth through conversion.

Even if accompanied by evangelism (that is, a clear and complete presentation of the gospel), outreach without the appropriate structures may be unfruitful. If a church has no culturally relevant programs or community-forming activities for the people whom church members are meeting through outreach, conversions may not result in the numerical growth of the church. For example, if an elderly congregation runs an after-school tutoring program in a primarily immigrant neighborhood, most youth who make some type of profession of faith will not find their needs for fellowship and discipleship met in such a congregation if no other youth ministry is present.

Nevertheless, outreach is essential for a church to grow because it is often the nonChristian's first contact point with people who have put their faith in Christ. Similarly, it is often the non-Christian's first contact with the church, which provides the community context necessary for biblical discipleship. In light of the Mum effect, outreach is especially important because no bad news is involved. The services and activities provided, as well as the interactions with the 
Christians involved in the outreach activities, are typically positive, responding to the needs and the desires of the non-Christians. Such relationship development enables trust to grow which permits a more complete sharing of the gospel in a credible way (Dunaetz, 2019) and mitigates the mum effect (Zanin, Bisel, \& Adame, 2016).

In addition, all Christians have the ability to do outreach when its purpose is defined as relationship building. Not all Christians may be verbally gifted to be an evangelist or have the spiritual gift of evangelism (Eph. 4:20, I Cor. 12:30, I Pet. 4:11), but all are called to love their neighbors. Verbal ability to communicate abstract concepts varies immensely between individuals (Fillmore, Kempler, \& Wang, 1979). Some Christians have limited cognitive abilities that make it difficult for them to accurately verbally express the abstract concepts that are part of the gospel. However, almost all Christians have the ability to develop relationships and act in a trustworthy manner, opening the hearts and minds of non-Christians to better prepare them for receiving and understanding the gospel message.

Although outreach is not enough to lead people to Christ, it is essential as a form of preevangelism (O'Neill, 1999) that enables all believers to develop relationships with non-believers which, in turn, can provide opportunities for the non-believers to hear the gospel and respond to it. In outreach, Christians do not need to share any bad news, thus making such interactions attractive to both Christians and non-Christians alike. Similarly, witnessing is within the ability of virtually all believers and does not necessarily trigger the psychological phenomena that produce the Mum effect.

\section{Witnessing: Telling Stories about One's Experiences with God}

Unlike outreach, witnessing is a concept explicitly mentioned in the Bible, usually with the word $\mu \alpha \rho \tau v \rho \varepsilon \dot{\omega} \omega$ which is often translated as to testify or to give testimony. It is a legal term which essentially means to verbally recount what one has personally seen or heard, to transmit information to another person about what one has perceived (Bauer, 1979, pp. 492-493; Strathmann, 1985). Although this might include conceptual abstractions, in most cases it involves talking about something one has experienced, typically by some sort of storytelling (Norrick, 2000). In a Christian context, witnessing, as defined this way, can include telling the story of how one became a Christian, of how God has worked in one's life since one's conversion, or about a specific instance of how God has acted in one's life.

Storytelling is perhaps the main way that people persuade one another of something. This is especially true when there is sympathy between two people due to having something in common or because of the nature of their relationship. When one person tells a story, including and perhaps especially a personal story, the storyteller pulls the listener into a conception of reality as the listener tries to understand the experience the storyteller is describing. Storytelling increases the meaning of the events for both the storyteller and the listener, integrating the story's underlying assumptions into a comprehensible worldview (Delgado, 1989; Lévi-Strauss, 1955). 
When Christians witness by telling the story of something that God has done in their life, they are strengthened in their faith as they put together the various pieces of God's interventions into an integrated narrative. When non-Christians listen to a story of how God has worked in a believer's life, they are invited into a worldview where God is active, transforming, and good. Such fundamental beliefs prepare them to respond to the gospel. Since witnessing is telling a personal narrative, the information presented is unlikely to be interpreted as bad news. This reduces the hesitancy to share the information associated with the Mum effect. Telling a personal story is much less threatening than communicating to a person all that he or she needs to know to respond to the gospel, as is the case with evangelism.

Like outreach, witnessing to what God has done in one's life is within the ability of virtually all Christians. The Samaritan woman at the well (John 4) serves as a paradigm for

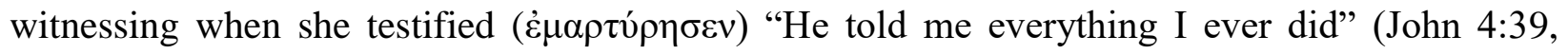
NIV). As with outreach, those uncomfortable or incapable of explaining abstract concepts may still easily share stories with those around them about what they have experienced with God.

In contemporary legal contexts, the defendant or plaintiff is expected to be able to testify, to tell what he or she has done, seen, or heard. However, it is the responsibility of the lawyer to argue the case, to pull all the testimonies together through analysis and synthesis, to make a comprehensive argument for how the judge and jury should respond. Similarly, an evangelist, one gifted in evangelism (Eph. 4:11), can argue for the need to follow Christ, providing the analysis and synthesis necessary for a non-Christian to understand the gospel and follow Christ. Such clear and structured presentations are all the more persuasive when the non-Christian has previously heard others' testimony of what God has done in their lives.

\section{Evangelism to Enable a Decision to Follow Christ}

In contrast to outreach and witnessing, evangelism can be defined as presenting the complete content of the gospel so that the listener both understands it and knows how to respond to it. Whereas outreach may prepare a person to be receptive the gospel, and witnessing may share parts of the gospel, evangelism defined this way includes the communication of everything that a non-Christian needs to know to become a believer. Evangelism is an essential aspect of the Great Commission (Matt. 28:19-20) because it provides the starting point for a life of discipleship.

Unlike outreach and witnessing, evangelism defined this way may not be within the abilities of all Christians. Evangelism, like all forms of teaching or transmitting information systematically, requires verbal skills and a clear and culturally relevant explanation of abstract concepts. An important concept in the New Testament is that not all Christians have the same spiritual gifts. For example, Peter exhorts Christians to use the spiritual gifts they have received to serve one another, dividing the gifts into two major categories, gifts of speaking and gifts of serving (I Pet. 4:10-11). Evangelism, along with preaching, teaching, counseling, and encouraging, would fall into the category of speaking gifts. Evangelism requires a skill set similar to teaching, a skill set that not every Christian possesses (James 3:1). 
Nevertheless, many people in churches have precisely the necessary skills and gifting for

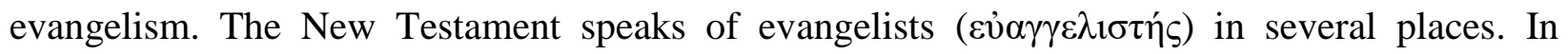
Ephesians 4:11 the evangelist is described as a gift to the church for equipping Christians for ministry. Philip, one of the seven chosen to serve tables (Acts 6:5), has a ministry of evangelism in Samaria (Acts 8) and is later described using the title of evangelist (Acts 21:8). Paul calls on Timothy to "do the work of an evangelist" (2 Tim. 4:5 NIV), apparently because there was a need for evangelism and Timothy was capable of it, yet perhaps a bit hesitant because he did not view it as his primary calling. Similarly, there are many people in contemporary churches, including most pastoral staff, who are quite capable of evangelism and, like Timothy, capable of doing "the work of an evangelist." These people should receive training in evangelism and be encouraged to use this gift whenever possible.

The presence of people gifted in evangelism who willingly share the gospel with others is an encouragement to Christians who are not gifted to do so. Whereas all Christians can help lay the foundation through outreach and witnessing, not everyone should be pressured into doing the work of an evangelist or be made to feel guilty if they do not regularly present the plan of salvation to non-believers, especially if they are not verbally gifted to do so. Those who are gifted in evangelism will most likely communicate the gospel more clearly than those who are not so gifted. Regular public presentations of the gospel by people appropriately gifted allow all Christians to invite their friends and relatives to hear such presentations and to build upon the foundation that they have laid through outreach and witnessing.

Sharing the gospel in large group settings (i.e., in groups large enough so that most audience members do not feel that they have a personal relationship with the speaker, such as Peter's experience at Pentecost, some of Philip's experiences in Samaria, and Paul's experiences in the synagogues) is especially important in light of the Mum effect. One-on-one gospel presentations are often awkward for both the presenter of the message and the receiver due to the Mum effect.

For the typical person without the appropriate abilities, trying to present a one-on-one gospel presentation may create feelings of coming across as judgmental, a sense of incompetence, the fear of rejection, and malaise from saying things which make the receiver uncomfortable. These strong negative feelings associated with the Mum effect have discouraged many people from doing one-on-one evangelism. When churches communicate that such evangelism should be normal for every Christian, Christians not only feel guilty, but may also be less likely to participate in relationship-building outreach and witnessing of what God has done in their lives because such activities may be viewed as insufficient, if not accompanied by gospel presentations.

One-on-one gospel presentations can also be awkward for the recipients of the message due to the Mum effect. Rather than communicating to the presenter the bad news that they do not want to make a decision to follow Christ or that they do not understand the message, to prevent both the presenter and recipient from losing face, they may give verbal assent to the message and even pray with the presenter, but with no intention of such a decision making a difference in their 
life (Sittser \& Calderon, 2018). This may effectively inoculate them against future gospel presentations.

These problems may be avoided in large group settings where the speaker has the gifts necessary to communicate the gospel clearly in a culturally appropriate manner and does not have a relationship with the non-Christians in the audience which can be damaged by sharing information that is perceived as bad news. Although the content of the message may evoke negative feelings in the listener due to the convicting work of the Holy Spirit, the presenter is less likely to lose face, experience a damaged relationship, or be mocked if the message is rejected, enabling him or her to focus on clearly communicating all that is necessary for the audience to respond to the gospel.

This does not imply that churches should give up training in personal evangelism or discourage one-on-one gospel presentations. Training in evangelism should be offered to all who are interested in developing their abilities to share the gospel; such training and the experiences to which it leads help people determine their gifting and how they can most effectively serve the Lord. However, a church program where the gospel is presented regularly and publicly gives all members the opportunity to bring non-Christian friends and relatives to hear it, people with whom they have perhaps developed a relationship through outreach activities or to whom they have been witnessing by sharing how God has worked in their lives.

\section{Conclusion}

Jesus' call to make disciples is among the top priorities given to the church. However, evangelism is difficult for many Christians because of a lack of gifting. The Mum effect, the hesitancy to share bad news, is due to negative feelings associated with making others feel uncomfortable, the fear of being rejected, and a desire to protect one's own reputation, feelings that are often associated with personal evangelism. In addition, the fear of being mocked or humiliated, as Christians often are in social media, makes many Christians even more hesitant to evangelize in one-on-one situations.

Although not all Christians may be able or willing to do personal evangelization, all can participate in outreach activities to develop relationships with non-Christians and all can be witnesses of how they have experienced Christ in their own lives. This outreach and witnessing can open doors leading to conversion if churches also provide large group presentations of the Gospel which enable these non-Christians to fully understand their need for Christ and to respond in a way that reduces the likelihood of losing face or damaging relationships. 


\section{References}

Altheide, D. L. (2013). Media logic, social control, and fear. Communication Theory, 23, 223-238.

Bakshy, E., Messing, S., \& Adamic, L. A. (2015). Exposure to ideologically diverse news and opinion on Facebook. Science, 348, 1130-1132.

Barna Group. (2015). Talking Jesus: Perceptions of Jesus, Christians and evangelicalism in England. Retrieved from http://www.talkingjesus.org/research/upload/Talking-Jesus.pdf

Bauer, W. (1979). A Greek-English lexicon of the New Testament and other early Christian literature (W. F. Arndt \& F. W. Gingrich, Trans. 2nd ed.). Chicago, IL: University of Chicago Press.

Bond, C. F., \& Anderson, E. L. (1987). The reluctance to transmit bad news: Private discomfort or public display? Journal of Experimental Social Psychology, 23, 176-187.

Colleoni, E., Rozza, A., \& Arvidsson, A. (2014). Echo chamber or public sphere? Predicting political orientation and measuring political homophily in Twitter using big data. Journal of Communication, 64, 317-332.

Conlee, M. C., \& Tesser, A. (1973). The effects of recipient desire to hear on news transmission. Sociometry, 36, 588-599.

Cropanzano, R., \& Mitchell, M. S. (2005). Social exchange theory: An interdisciplinary review. Journal of Management, 31, 874-900.

Deci, E. L., \& Ryan, R. M. (2008). Self-determination theory: A macrotheory of human motivation, development, and health. Canadian Psychology/Psychologie Canadienne, 49, 182-185.

Delgado, R. (1989). Storytelling for oppositionists and others: A plea for narrative. Michigan Law Review, 87, 24112441.

Dibble, J. L. (2017). It's more than self-presentation: Mum effects can reflect private discomfort and concern for the recipient. Communication Research Reports, 1-9.

Dibble, J. L., \& Levine, T. R. (2013). Sharing good and bad news with friends and strangers: Reasons for and communication behaviors associated with the mum effect. Communication Studies, 64, 431-452.

Dunaetz, D. R. (2019). Missionary credibility: Characteristics of the messenger that make the message more persuasive. In D. R. Dunaetz (Ed.), God first: Essays in honor of Michael M. Whyte and Gary D. Lemaster (pp. 187-199). Claremont, CA: Martel Press.

Dunaetz, D. R., Lisk, T. C., \& Shin, M. (2015). Personality, gender, and age as predictors of media richness preference. Advances in Multimedia, 2015, 1-9.

Dunaetz, D. R., \& Priddy, K. E. (2014). Pastoral attitudes that predict numerical Church Growth. Great Commission Research Journal, 5, 241-256.

Eberstadt, M. (2016). Regular Christians are no longer welcome in American culture. Time. Retrieved from http://time.com/4385755/faith-in-america/

Fallowfield, L. J., Jenkins, V. A., \& Beveridge, H. A. (2002). Truth may hurt but deceit hurts more: Communication in palliative care. Palliative Medicine, 16, 297-303.

Fazio, R. H. (1979). Motives for social comparison: The construction-validation distinction. Journal of Personality and Social Psychology, 37, 1683-1698.

Festinger, L. (1954). A theory of social comparison processes. Human Relations, 7, 117-140.

Fillmore, C. J., Kempler, D., \& Wang, W. S. Y. (1979). Individual differences in language ability and language behavior. New York, NY: Academic Press.

Hatfield, E., Cacioppo, J. T., \& Rapson, R. L. (1993). Emotional contagion. Current Directions in Psychological Science, 2, 96-100.

Jones, E. E. (1964). Ingratiation, a social psychological analysis. New York, NY: Appleton-Century-Crofts.

Jones, E. E., \& Wortman, C. B. (1973). Ingratiation: An attributional approach. New York, NY: General Learning Press.

Kelly, W. D., \& Friesen, S. R. (1950). Do cancer patients want to be told? Surgery, 27, 822-826. 
Kowalski, R. M., Giumetti, G. W., Schroeder, A. N., \& Lattanner, M. R. (2014). Bullying in the digital age: A critical review and meta-analysis of cyberbullying research among youth. Psychological Bulletin, 140, 1073-1137.

Kramer, A. D., Guillory, J. E., \& Hancock, J. T. (2014). Experimental evidence of massive-scale emotional contagion through social networks. Proceedings of the National Academy of Sciences, 111, 8788-8790.

Leary, M. R. (1990). Responses to social exclusion: Social anxiety, jealousy, loneliness, depression, and low selfesteem. Journal of Social and Clinical Psychology, 9, 221-229.

Leary, M. R. (1996). Self-presentation: Impression management and interpersonal behavior. Boulder, CO: Westview Press.

Leary, M. R., Tambor, E. S., Terdal, S. K., \& Downs, D. L. (1995). Self-esteem as an interpersonal monitor: The sociometer hypothesis. Journal of personality and social psychology, 68, 518-530.

Lenhart, A., Purcell, K., Smith, A., \& Zickuhr, K. (2010). Social media \& mobile internet use among teens and young adults. Millennials. Pew internet \& American life project. Retrieved from http://files.eric.ed.gov/fulltext/ED525056.pdf

Lévi-Strauss, C. (1955). The structural study of myth. The Journal of American Folklore, 68, 428-444.

Longman. (2015). Outreach in sociology. Retrieved from Longman Dictionary of Contemporary English website: https://www.ldoceonline.com/Sociology-topic/outreach

Manis, M., Cornell, S. D., \& Moore, J. C. (1974). Transmission of attitude relevant information through a communication chain. Journal of Personality and Social Psychology, 30, 81-94.

McPherson, J. M., Smith-Lovin, L., \& Cook, J. M. (2001). Birds of a feather: Homophily in social networks. Annual Review of Sociology, 27, 415-444.

MediaSmarts. (n.d.). Media portrayals of religion: Christianity. Retrieved from MediaSmarts: Canada's Centre for Digital and Media Literacy website: $\underline{\text { http://mediasmarts.ca/diversity-media/religion/media-portrayals- }}$ religion-christianity

Norrick, N. R. (2000). Conversational narrative: Storytelling in everyday talk. Amsterdam, NL: John Benjamins Publishing.

O'Neill, D. J. (1999). Teaming up with God: A theology of pre-evangelism. New York, NY: Harcourt Custom Publishers.

Pew Research Center. (2014). How Americans feel about religious groups. Retrieved from http://assets.pewresearch.org/wp-content/uploads/sites/11/2014/07/Views-of-Religious-Groups-07-27-fullPDF-for-web.pdf

Poushter, J. (2016). Smartphone ownership and internet usage continues to climb in emerging economies. Pew Research Center, 22. Retrieved from http://s1.pulso.cl/wp-content/uploads/2016/02/2258581.pdf

Rosen, S., \& Tesser, A. (1970). On reluctance to communicate undesirable information: The mum effect. Sociometry, 253-263.

Ryan, R. M., \& Deci, E. L. (2000). Self-determination theory and the facilitation of intrinsic motivation, social development, and well-being. American Psychologist, 55, 68-78.

Sittser, G. L., \& Calderon, C. (2018). Discipleship in Christendom . . And beyond. Evangelical Missions Quarterly, 54, 25-30.

Strathmann, H. (1985). Martys [witness]. In G. W. Bromily (Ed.), Theological dictionary of the New Testament (pp. 564-570). Grand Rapids, MI: Erdmans/Paternoster.

Swann, W. B. (1990). To be adored or to be known? The interplay of self-enhancement and self-verification. In E. T. Higgins \& R. M. Sorrentino (Eds.), Handbook of motivation and cognition: Foundations of social behavior (Vol. 2, pp. 408-448). New York, NY: Guilford Press.

Tesser, A., \& Conlee, M. C. (1973). Recipient emotionality as a determinant of the transmission of bad news. Proceedings of the Annual Convention of the American Psychological Association, 247-248.

Tesser, A., \& Rosen, S. (1975). The reluctance to transmit bad news Advances in experimental social psychology (Vol. 8, pp. 193-232). San Diego, CA: Elsevier. 
Tesser, A., Rosen, S., \& Batchelor, T. R. (1972). On the reluctance to communicate bad news (the mum effect): A role play extension. Journal of Personality, 40, 88-103.

Twenge, J. M. (2014). Generation me: Why today's young Americans are more confident, assertive, entitled--and more miserable than ever before (Rev. ed.). New York, NY: Atria.

Twenge, J. M. (2017). Have smartphones destroyed a generation? The Atlantic. Retrieved from https://www.theatlantic.com/magazine/archive/2017/09/has-the-smartphone-destroyed-ageneration/534198/

Twenge, J. M., Joiner, T. E., Rogers, M. L., \& Martin, G. N. (2018). Increases in depressive symptoms, suiciderelated outcomes, and suicide rates among US adolescents after 2010 and links to increased new media screen time. Clinical Psychological Science, 6, 3-17.

Uysal, A., \& Öner-Özkan, B. (2007). A self-presentational approach to transmission of good and bad news. Social Behavior and Personality: An International Journal, 35, 63-78.

Vogel, E. A., Rose, J. P., Roberts, L. R., \& Eckles, K. (2014). Social comparison, social media, and self-esteem. Psychology of Popular Media Culture, 3, 206-222.

Zanin, A. C., Bisel, R. S., \& Adame, E. A. (2016). Supervisor moral talk contagion and trust-in-supervisor: Mitigating the workplace moral mum effect. Management Communication Quarterly, 30, 147-163. 